\title{
Phytoprotection
}

\section{Weed economic thresholds : Useful agronomic tool or pipe dream?}

\section{J.T. O’Donovan}

Volume 77, numéro 1, 1996

URI : https://id.erudit.org/iderudit/706097ar

DOI : https://doi.org/10.7202/706097ar

Aller au sommaire du numéro

\section{Éditeur(s)}

Société de protection des plantes du Québec (SPPQ)l

\section{ISSN}

0031-9511 (imprimé)

1710-1603 (numérique)

\section{Découvrir la revue}

\section{Citer cet article}

O'Donovan, J. (1996). Weed economic thresholds : Useful agronomic tool or pipe dream? Phytoprotection, 77(1), 13-28. https://doi.org/10.7202/706097ar

\section{Résumé de l'article}

L'intérêt pour des approches de lutte contre les mauvaises herbes plus ration nelles et objectives s'est considérablement accru au Canada et ailleurs. Les questions de coût/bénéfices, les préoccupations environnementales et le développement de la résistance aux herbicides ont semé le doute sur la pertinence et la possibilité de poursuivre l'utilisation préventive des herbicides. Le concept de seuil d'intervention économique pour les mauvaises herbes et le concept plus large de lutte intégrée présentent un potentiel important comme outils agronomiques pratiques dans les systèmes de production canadiens. Un grand nombre d'expériences ont été menées afin de déterminer l'impact des mauvaises herbes sur le rendement des cultures, mais les modèles développés à partir de ces études ont été peu mis en pratique. Les contraintes à la mise en pratique de ces concepts comprennent l'absence de protocoles d'échantillonnage réalistes afin de déterminer l'impact des mauvaises herbes sur les cultures sur de vastes étendues, ainsi qu'un manque de renseignements sur les implications à long terme de la production de graines par les mauvaises herbes non contrôlées. Les malherbologistes qui mènent des expériences sur l'interférence causée par les mauvaises herbes devraient mieux définir leurs objectifs et devraient fournir des directives sur la façon dont leurs résultats peuvent être utilisés à la ferme. L'accent devrait être placé sur l'effet des cultures sur les mauvaises herbes plutôt que sur l'effet des mauvaises herbes sur les cultures. Une meilleure coordination des activités de recherche des malherbologistes s'impose. La mise en place de protocoles standards pour les études à long terme entre les sites et les années augmenterait la pertinence et la précision des modèles d'interférence, et pourrait conduire au développement de systèmes d'aide à la décision conviviaux et adaptés spécifiquement à la prise de décisions rationnelles de lutte contre les mauvaises herbes dans les systèmes canadiens de production des cultures. Le développement de tels systèmes sera essentiel à la mise en place de seuils d'intervention et de méthodes de lutte intégrée contre les mauvaises herbes.
Ce document est protégé par la loi sur le droit d'auteur. L'utilisation des services d'Érudit (y compris la reproduction) est assujettie à sa politique d'utilisation que vous pouvez consulter en ligne.

https://apropos.erudit.org/fr/usagers/politique-dutilisation/ 


\title{
Weed economic thresholds : Useful agronomic tool or pipe dream?
}

\author{
John T. O'Donovan'
}

Received 1995-07-19; accepted 1996-03-31

Interest in more rational and objective approaches to weed management has increased considerably in Canada and elsewhere. Cost/benefit issues, environmental concerns, and the development of weed resistance to herbicides have cast doubt on the rationality and sustainability of prophylactic herbicide use. The concept of an economic threshold for weeds and the broader concept of integrated weed management have considerable potential as practical agronomic tools in Canadian crop production systems. A large number of experiments have been conducted to determine the impact of weeds on crop yield, but the models developed from these studies have been put to little practical use. Constraints to the practical implementation of these concepts include a lack of realistic sampling procedures to assess the impact of weeds on crops over large areas, and a lack of information on the long-term implications of seed production by uncontrolled weeds. Weed ecologists conducting weed interference experiments should define their objectives better, and should provide guidelines on how their findings can be used at the farm level. Emphasis should be placed on the effects of the crop on the weed rather than the weed on the crop. There is also a need for greater coordination of research activities among weed ecologists. The establishment of standard protocols for long-term studies across locations and years would enhance the relevance and precision of weed interference models, and lead to the development of userfriendly decision support systems specifically adapted to aiding rational weed management decisions in Canadian crop production systems. The development of such systems will be essential to the implementation of weed thresholds and integrated weed management.

O'Donovan, J.T. 1996. Seuils économiques d'intervention : outil agronomique utile ou utopie? PHYTOPROTECTION 77 : 13-28.

L'intérêt pour des approches de lutte contre les mauvaises herbes plus rationnelles et objectives s'est considérablement accru au Canada et ailleurs. Les questions de coût/bénéfices, les préoccupations environnementales et le développement de la résistance aux herbicides ont semé le doute sur la pertinence et la possibilité de poursuivre l'utilisation préventive des herbicides. Le concept de seuil d'intervention économique pour les mauvaises herbes et le concept plus large de lutte intégrée présentent un potentiel important comme

1. Alberta Environmental Centre, Postal Bag 4000, Vegreville, Alberta, Canada T9C 1T4 
outils agronomiques pratiques dans les systèmes de production canadiens. Un grand nombre d'expériences ont été menées afin de déterminer l'impact des mauvaises herbes sur le rendement des cultures, mais les modèles développés à partir de ces études ont été peu mis en pratique. Les contraintes à la mise en pratique de ces concepts comprennent l'absence de protocoles d'échantillonnage réalistes afin de déterminer l'impact des mauvaises herbes sur les cultures sur de vastes étendues, ainsi qu'un manque de renseignements sur les implications à long terme de la production de graines par les mauvaises herbes non contrôlées. Les malherbologistes qui mènent des expériences sur l'interférence causée par les mauvaises herbes devraient mieux définir leurs objectifs et devraient fournir des directives sur la façon dont leurs résultats peuvent être utilisés à la ferme. L'accent devrait être placé sur l'effet des cultures sur les mauvaises herbes plutôt que sur l'effet des mauvaises herbes sur les cultures. Une meilleure coordination des activités de recherche des malherbologistes s'impose. La mise en place de protocoles standards pour les études à long terme entre les sites et les années augmenterait la pertinence et la précision des modèles d'interférence, et pourrait conduire au développement de systèmes d'aide à la décision conviviaux et adaptés spécifiquement à la prise de décisions rationnelles de lutte contre les mauvaises herbes dans les systèmes canadiens de production des cultures. Le développement de tels systèmes sera essentiel à la mise en place de seuils d'intervention et de méthodes de lutte intégrée contre les mauvaises herbes.

\section{INTRODUCTION}

In Canada and elsewhere, weed control with herbicides traditionally has been habitual. Farmers have applied herbicides routinely without giving much consideration to cost/benefit aspects of the practice. Interest in more rational and objective approaches to weed control has increased considerably in recent years, and is being driven by several concerns. First, the environmental consequences of prophylactic herbicide use, especially in relation to ground water contamination, are coming under closer scrutiny (Swanton and Weise 1991); second, relatively low crop prices are forcing farmers to reduce pesticide and other input costs to remain profitable; and finally, weed resistance to herbicides is on the increase and casts doubt on the sustainability of continuous herbicide use. In western Canada alone, weeds such as green foxtail [Setaria viridis (L.) Beauv.] (Morrison et al. 1989), wild oats (Avena fatua L.) (Heap et al. 1993; O'Donovan et al. 1994a) and chickweed [Stellaria media (L.) Vill.] (O'Donovan et al. 1994b) have become highly resistant to several commonly used herbicides in a number of locations.

Conceivably, rational decisions on controlling weeds with herbicides would be more feasible if the cost/benefit of weed control could be assessed objectively. This has led to the concept of the weed economic threshold, which can be broadly defined as the weed density at which the cost of control (with herbicides) equals the financial return on the recovered crop yield. For the purpose of this review, this type of threshold will be referred to as the single season threshold. Opinions on the practical application of weed thresholds and other bioeconomical approaches to weed management range from optimism (Gerowitt and Heitefuss 1990; Poole and Gill 1987; Wilkerson et al. 1991) to pessimism (Cousens 1992; Norris 1992a).

This paper discusses the problems associated with the development and implementation of weed economic thresholds with emphasis on their potential usage in Canadian crop production systems. 


\section{YIELD LOSS AS A FUNCTION OF WEED DENSITY}

A major component of a weed economic threshold model is a measure of the potential crop yield loss caused by the weeds. Weed density has been the variable most often used to develop empirical yield loss models. Such models usually are derived from additive field experiments where crop density is held relatively constant, and weed density is varied. Dew (1972) was one of the first weed scientists in Canada to develop a functional relationship between crop yield loss and weed density. He used simple linear regression techniques to develop competitive indices for estimating wheat (Triticum aestivum L.), barley (Hordeum vulgare L.) and flax (Linum usitatissimum L.) yield losses due to wild oats. The relationship between crop yield and wild oats density was described by the model shown in Eq. [1] :

$$
y=a+b d
$$

where $y$ is the estimated crop yield, $a$ is the intercept (estimated weed-free crop yield), $b$ is the slope and $d$ is the weed density (plants $\mathrm{m}^{-2}$ ). A competitive index (b/a) was developed for each wild oatscrop combination. A similar index was later developed for canola (Brassica napus L.) (Dew and Keys 1976). The accuracy of these indices in estimating wheat and barley yield losses due to wild oats in western Canada was confirmed by Hamman (1979).

Since then, there has been a considerable amount of research in Canada to quantify the relationship between crop yield (or yield loss) and density of several other weed species (Table 1).

There has been considerable discussion on the shape of the relationship between crop yield loss and weed population density. Dew (1972) recognized the importance of intraspecific competition at high weed densities and achieved a curvilinear response by square-root transformation of the independent variable (weed density) prior to linear regression analysis. A more biologically mean- ingful nonlinear regression model was proposed later by Cousens (1985), and has gained widespread acceptance as an appropriate regression model for describing the relationship between crop yield loss and weed density. The model is described in Eq. [2].

$$
y=Y_{w f} \quad\left[1-\frac{i d}{100(1+i d / a)}\right]
$$

where $y$ is the estimated crop yield, $Y_{w t}$ is the estimated weed-free yield, $i$ is the initial slope, $d$ is the weed density, and a is the asymptote.

Numerous experiments have indicated, and it is now generally acknowledged that at low weed population densities the yield loss response tends towards linearity. As density increases, weeds begin to compete intraspecifically, and yield loss approaches an asymptote (Cousens 1985). The wisdom of continuing to conduct labor-intensive weed interference experiments, for the sole purpose of reinforcing this well-established conclusion, has been questioned (Cousens 1987; Norris 1992a).

\section{ESTIMATING SINGLE-SEASON ECONOMIC THRESHOLDS}

Although various models have been published to describe the magnitude of the yield loss caused by weeds in Canada, particularly weed density, relatively few attempts have been made to extend the models to estimate the cost/benefit of weed control with herbicides (Moyer and Schaalje 1993; O'Donovan 1991; O'Donovan et al. 1987; Weaver 1991). This is unfortunate, since crop yield loss should not be the only criterion used in the decision-making process. Other information, including economic factors such as herbicide and application costs, and expected crop yields and prices at harvest must also be considered (Marra and Carlson 1983).

Where the response of crop yield to weed density is linear, single-season thresholds can be calculated by extending the model described in Eq. [1] to 
Table 1. Reported studies on the relationship between crop yield and weed density in Canada

\begin{tabular}{|c|c|c|}
\hline Weed & Crop & Reference \\
\hline $\begin{array}{l}\text { Abutilon theophrasti Medic. } \\
\text { Avena fatua } L \text {. }\end{array}$ & $\begin{array}{l}\text { Glycine max (L.) Merr. } \\
\text { Triticum aestivum L. (sw) } \\
\text { Hordeum vulgare L. } \\
\text { Brassica napus L. }\end{array}$ & $\begin{array}{l}\text { Weaver } 1991 \\
\text { Dew } 1972 \\
\text { Kirkland and Hunter } 1991 \\
\text { Dew } 1972 \\
\text { Dew and Keys } 1976\end{array}$ \\
\hline Bromus tectorum $\mathrm{L}$. & $\begin{array}{l}\text { Triticum aestivum L. (ww) } \\
\text { Secale cereale L. }\end{array}$ & $\begin{array}{l}\text { Blackshaw 1993a } \\
\text { Blackshaw 1993a }\end{array}$ \\
\hline Chenopodium album L. & $\begin{array}{l}\text { Brassica oleracea L. } \\
\text { Brassica napus L. }\end{array}$ & $\begin{array}{l}\text { Bitterlich and Upadhyaya } 1990 \\
\text { Blackshaw et al. } 1987\end{array}$ \\
\hline Cirsium arvense (L.) Scop. & $\begin{array}{l}\text { Triticum aestivum } \mathrm{L} . \quad(\mathrm{ww}) \\
\text { Medicago sativa } \mathrm{L} \text {. } \\
\text { Hordeum vulgare } \mathrm{L} \text {. } \\
\text { Brassica napus } \mathrm{L} \text {. }\end{array}$ & $\begin{array}{l}\text { McLennan et al. } 1991 \\
\text { Moyer et al. } 1991 \\
\text { O'Sullivan et al. } 1982 \\
\text { O'Sullivan et al. } 1985\end{array}$ \\
\hline Datura stramonium $\mathrm{L}$. & Glycine $\max$ (L.) Merr. & Weaver 1986, 1991 \\
\hline Elytrigia repens (L.) Nevski & $\begin{array}{l}\text { Medicago sativa } \mathrm{L} \text {. } \\
\text { Brassica rapa } \mathrm{L} \text {. } \\
\text { Hordeum vulgare } \mathrm{L} \text {. }\end{array}$ & $\begin{array}{l}\text { Moyer and Schaalje } 1993 \\
\text { Pageau and Leroux } 1988 \\
\text { O'Donovan } 1991 \\
\text { Rioux } 1982\end{array}$ \\
\hline Fagopyrum tataricum (L.) Gaertn. & $\begin{array}{l}\text { Triticum aestivum } \mathrm{L} \text {. (sw) } \\
\text { Hordeum vulgare } \mathrm{L} \text {. }\end{array}$ & De St. Remy et al. 1985 \\
\hline Galeopsis tetrahit $\mathrm{L}$. & $\begin{array}{l}\text { Avena sativa } \mathrm{L} \text {. } \\
\text { Medicago sativa } \mathrm{L} \text {. }\end{array}$ & Légère and Deschênes 1991 \\
\hline Malva pusilla Sm. & $\begin{array}{l}\text { Triticum aestivum L. (sw) } \\
\text { Linum usitatissimum } \mathrm{L} .\end{array}$ & Friesen et al. 1992 \\
\hline Matricaria perforata Mérat & $\begin{array}{l}\text { Triticum aestivum L. (ww) } \\
\text { Triticum aestivum L. (sw) }\end{array}$ & $\begin{array}{l}\text { Douglas et al. } 1991 \\
\text { Douglas et al. } 1992\end{array}$ \\
\hline Mixed species & $\begin{array}{l}\text { Triticum aestivum L. } \\
\text { Brassica napus L. } \\
\text { Glycine max (L.) Merr. }\end{array}$ & $\begin{array}{l}\text { Hume } 1989 \\
\text { Jolliffe et al. } 1984 \\
\text { Van Acker et al. } 1993\end{array}$ \\
\hline Polygonum lapathifolium L. & $\begin{array}{l}\text { Triticum aestivum } \mathrm{L} \text {. } \\
\text { Hordeum vulgare } \mathrm{L} . \\
\text { Brassica rapa } \mathrm{L} \text {. }\end{array}$ & O'Donovan 1994a \\
\hline Setaria viridis $L$. & $\begin{array}{l}\text { Hordeum vulgare } \mathrm{L} . \\
\text { Brassica rapa } \mathrm{L} . \\
\text { Solanum tuberosum } \mathrm{L} \text {. }\end{array}$ & $\begin{array}{l}\text { Blackshaw et al. } 1981 \\
\text { Hume } 1989 \\
\text { O'Donovan 1994a } \\
\text { O'Donovan 1994a } \\
\text { O'Donovan 1994a } \\
\text { Wall and Friesen } 1990\end{array}$ \\
\hline Silene vulgaris (Moench) Garcke & Medicago sativa L. & Wall and Morrison 1990 \\
\hline Sinapis arvensis $\mathrm{L}$. & $\begin{array}{l}\text { Brassica napus } \mathrm{L} . \\
\text { Phaseolus vulgaris } \mathrm{L} \text {. } \\
\text { Pisum sativum } \mathrm{L} \text {. }\end{array}$ & $\begin{array}{l}\text { Blackshaw et al. } 1987 \\
\text { Wall } 1993 \\
\text { Wall et al. } 1991\end{array}$ \\
\hline Solanum sarrachoides Sendtner & Phaseolus vulgaris L. & Blackshaw 1991 \\
\hline Solanum spp. & Glycine max (L.) Merr. & Weaver et al. 1987 \\
\hline $\begin{array}{l}\text { Sonchus arvensis } \mathrm{L} \text {. } \\
\text { Triticum aestivum and Hordeum vulgare } \\
\text { (volunteer cereals) }\end{array}$ & $\begin{array}{l}\text { Brassica napus } \mathrm{L} . \\
\text { Brassica napus } \mathrm{L} . \\
\text { Brassica rapa } \mathrm{L} \text {. }\end{array}$ & $\begin{array}{l}\text { Peschken et al. } 1983 \\
\text { Marshall et al. } 1989 \\
\text { O'Donovan et al. 1988, } 1989\end{array}$ \\
\hline Xanthium strumarium L. & $\begin{array}{l}\text { Linum usitatissimum } \mathrm{L} \text {. } \\
\text { Glycine } \max \mathrm{L} \text {. }\end{array}$ & $\begin{array}{l}\text { Friesen et al. } 1990 \\
\text { Weaver } 1991\end{array}$ \\
\hline
\end{tabular}

${ }^{a}$ sw : spring wheat; ww : winter wheat. 
include economic factors, as shown in Eq. [3].

$$
E=\frac{1-(C P-H) / C P}{L}
$$

where $E$ is the economic threshold weed density (plants $\left.\mathrm{m}^{-2}\right), C$ is the expected weed-free crop yield $\left(\mathrm{t} \mathrm{ha}^{-1}\right), P$ is the crop market price $\left(\$ t^{-1}\right), H$ is the cost of the herbicide and its application $\left(\$ \mathrm{t}^{-1}\right)$, and $L$ is the ratio b/a from Eq. [1]. Where the response is nonlinear, Eq. [3] can be extended as described by O'Donovan (1991) to incorporate the $i$ and a parameters of the nonlinear hyperbolic Eq. [2], as described in Eq. [4].

$$
E=\frac{1-(C P-H) / C P}{(r-s)+s((C P-H) / C P)}
$$

where $r$ is $i / 100$ and $s$ is i/a.

The threshold approach to weed management is succeeding in some countries, including Germany, where the decision to spray based on the use of fixed threshold values was more profitable than prophylactic herbicide application (Gerowitt and Heitefuss 1990). The threshold values were 20-30 plants $\mathrm{m}^{-2}$ for grass weeds (excluding wild oats) and 40-50 plants $\mathrm{m}^{-2}$ for broadleaved weeds [excluding Galium aparine L. and Fallopia convolvulus (L.) A. Löve]. In western Australia, brome grass (Bromus diandrus Roth) density measured within 4-6 wk of crop emergence correlated well with wheat yield loss, and under normal agronomic practices could be used to predict yield loss over large agricultural areas and across seasons (Poole and Gill 1987).

Wild oats, Canada thistle [Cirsium arvense (L.) Scop] and quackgrass [Elytrigia repens (L.) Nevski) are three of western Canada's most serious weeds in terms of their overall abundance and their ability to compete with crops. They are also relatively expensive to control with herbicides. Single-season economic thresholds calculated from Eq. [3] and Eq. [4] for these weeds are presented in Figures 1 and 2. Crop yield loss regression equation parameters developed for wild oats by Dew (1972) and Dew and Keys (1976), for Canada thistle by O'Sullivan et al. (1985) and for quackgrass by O'Donovan
(1991) were used in the models. It is evident that the threshold estimates varied considerably, depending on prices and potential yields of the crops. Thresholds tended to decrease as crop prices and yields increased. For example, wild oats thresholds varied from 9 to 115 plants $\mathrm{m}^{-2}$ in barley, and from 3 to 30 plants $\mathrm{m}^{-2}$ in wheat (Fig. 1). Single-season thresholds reported for wild oats in cereal crops in the United Kingdom were 8 to 12 plants $\mathrm{m}^{-2}$ (Cousens et al. 1985). These relatively lower threshold values probably reflect the higher crop prices in the United Kingdom compared to Canada. In canola, threshold values for wild oats were close to those for Canada thistle (Fig. 2), even though Canada thistle is considered more competitive than wild oats (O'Sullivan et al. 1982). In this case, the threshold values were influenced considerably by the higher herbicide cost for Canada thistle control (Fig. 2).

Thus, measuring and presenting crop yield loss data alone sheds little light on whether or not weed control with herbicides is economical. The economics of herbicide use must be determined by a combination of yield loss, crop price, crop yield productivity, and herbicide and application costs. These factors must be considered if weed yield loss models are to have a practical application in Canadian agriculture.

\section{DIFFICULTIES ASSOCIATED WITH WEED THRESHOLDS}

The concept of using single-season weed economic thresholds as a weed management tool has been criticized as being theoretical, and difficult to implement on a practical basis (Cousens 1987, 1992; Morin et al. 1993; Norris 1992a). Cousens (1987) suggests that almost all discussion on thresholds has been conceptual and not based on practical experience. It has been suggested that thresholds place excessive emphasis on weed density as a measure of crop yield loss, lack precision and tend to be site and year specific, are usually applicable to only one weed species, are difficult to assess and implement due to factors such as time constraints and weed patchiness, and fail to deal with the long-term impact of seed 


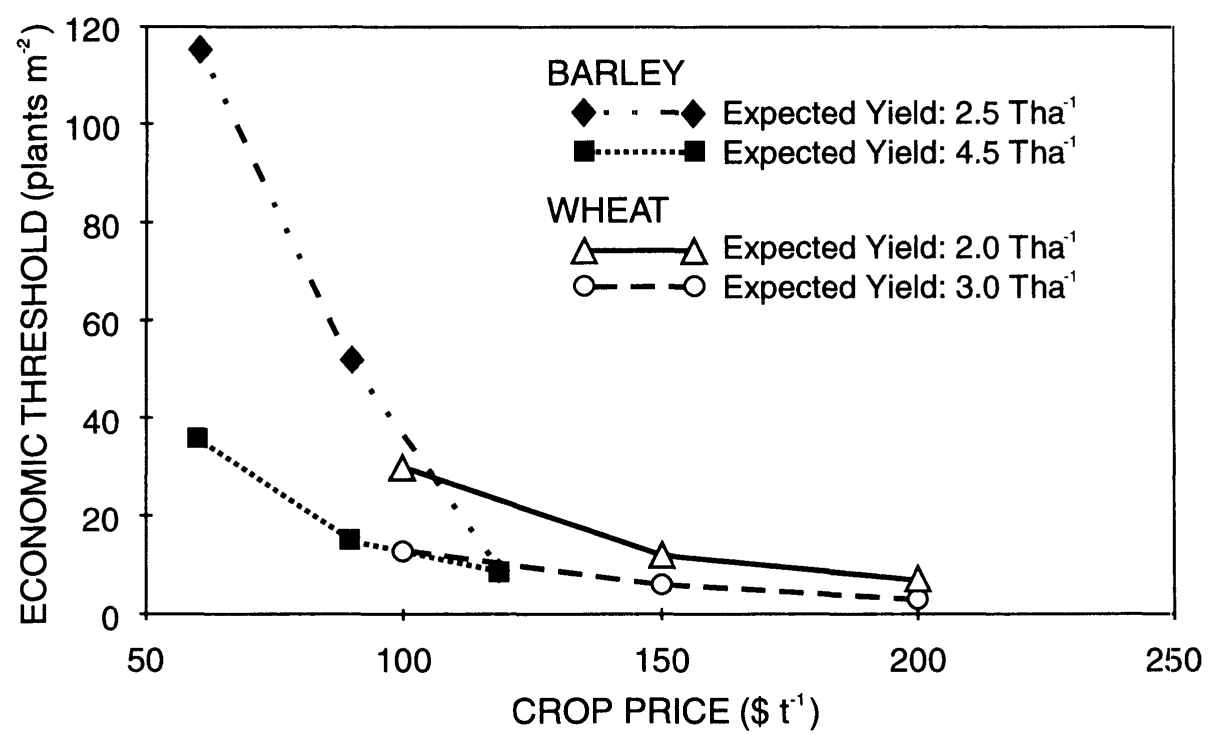

Figure 1. Calculated economic thresholds for wild oats in barley and wheat at two levels of expected yields. Herbicide and application costs for season-long control were assumed to be $\$ 37$ ha $^{-1}$.

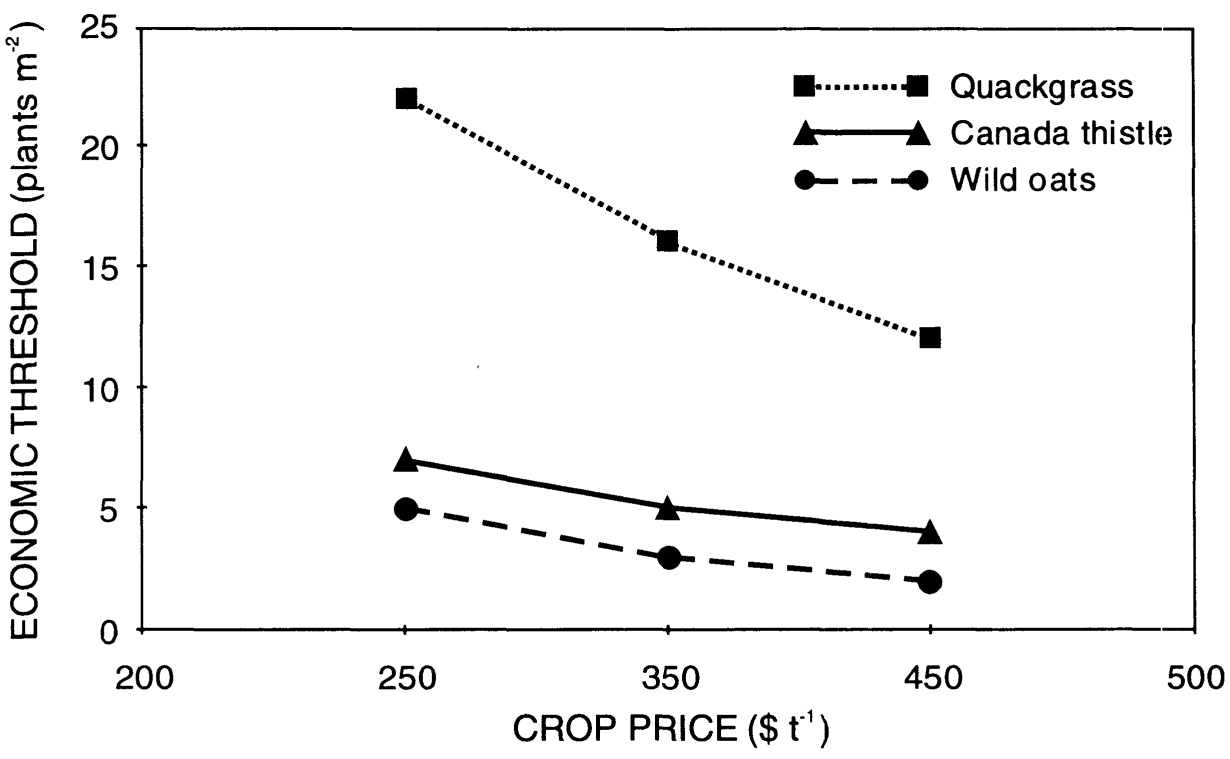

Figure 2. Calculated economic thresholds for wild oats, quackgrass and Canada thistle in canola at an expected canola yield of $2.0 \mathrm{t} \mathrm{ha}^{-1}$. Herbicide and application costs for season-long control were assumed to be $\$ 37, \$ 43$ and $\$ 52 \mathrm{ha}^{-1}$, respectively. 
rain from uncontrolled weeds in fields below the threshold. For weed thresholds and bioeconomic modelling to be a realistic and viable agronomic tool in Canadian agriculture, the following issues and complexities related to calculating thresholds need to be recognized and addressed.

\section{Factors other than weed density influence crop/weed interactions}

While the shape of the weed density response curve has been relatively consistent among the various crop and weed species studied, the magnitude of the response of crop yield to a specific weed density can vary considerably among locations and years. Some of this variation can be accounted for by differences in times of emergence of the weed and crop (Blackshaw 1993a; O'Donovan et al. 1985). In weed interference studies designed to assess the effects of weed density on crop yield, weeds and crops usually are seeded to emerge at the same time. In some cases in cultivated fields, the first flush of weeds can emerge close to the same time as the crop, especially when the weed and crop are closely related (e.g., wild oats and wheat). More often than not, however, weeds and crops emerge at different times relative to each other. Yield loss estimates from these models may be very inaccurate in such situations. For example, at a given wild oats density, yield loss in barley and wheat increased by approximately $2.5 \%$ for every day wild oats emerged before the crop (O'Donovan et al. 1985). Conversely, yield loss decreased by the same amount for every day wild oats emerged after the crop. Cousens et al. (1987) extended the hyperbolic yield loss Eq. [2] to incorporate time of emergence, as well as weed density, as follows in Eq. [5].

$$
y=Y_{w f}\left[1-\frac{i d}{100\left(\mathrm{e}^{\mathrm{ct}}+i d / a\right)}\right]
$$

where $e$ is the base of natural logarithms, $c$ is a nonlinear regression coefficient, and $t$ is relative time of emergence of the weed and crop.

From a practical standpoint, assessing relative times of emergence of weeds and crops as well as weed density should provide more accurate estimates of crop yield loss than weed density alone. To achieve this, however, close monitoring of fields at the time of and after crop emergence is required to determine when the first weed flushes occur. In a study conducted in the Netherlands, the hyperbolic Eq. [2] was modified to incorporate a single damage coefficient based on both weed density and relative time of emergence (Kropff and Spitters 1991). The model described in Eq. [6] relates yield loss to relative leaf area shortly after crop emergence.

$$
Y_{1}=\frac{q L}{1+L_{w}(q-1)}
$$

where $Y_{1}$ is percentage crop yield loss, $q$ is a relative damage coefficient, and $L_{w}$ is the relative leaf area of the weeds.

Economic thresholds can be calculated from this equation based on weed relative leaf area index rather than weed density (Weaver 1991). The main advantage of Eq. [6] over Eq. [5] is that the effect of two variables is described by one coefficient, and it can be used when weeds emerge in separate flushes. It may be difficult to implement on a practical basis, however, since at present there are no simple and accurate methods available to estimate relative leaf cover. Development of such methods should form a major focus of future weed/crop interference studies.

Crop density often has been ignored as a variable in weed interference models. Since farmers seed at a recommended optimum crop seeding rate, it is assumed that seedling emergence is relatively uniform throughout the field. However, Hume (1985) showed that wheat density in adjacent quadrats in Saskatchewan fields can vary considerably, and that estimates of crop yield loss due to weeds can be highly distorted if crop density is not taken into account. In experiments where wheat (Carlson and Hill 1985; Radford et al. 1980) and barley (Evans et al. 1991; Kirkland 1993) densities were varied intentionally, crop yield losses due to wild oats were less at high than at low crop seeding rates. Cousens (1985) proposed a nonlinear model to describe the relationship between crop 
yield loss and both weed and crop density, as shown in Eq. [7].

$$
y=\frac{a c}{1+b c+f d}
$$

where $c$ is crop density, $d$ is weed density, and $a, b$ and $f$ are nonlinear regression coefficients.

In Canada, Eq. [7] has been used to describe the effects of different densities of volunteer barley (O'Donovan et al. 1988), volunteer wheat (O'Donovan et al. 1989) and Tartary buckwheat [Fagopyrum tataricum (L.) Gaertn.] (O'Donovan 1994b) on canola yield at different canola plant densities. At a specific seeding rate, canola density can vary considerably among years and locations ( $O$ 'Donovan et al. 1988), and is influenced by many factors including seedbed firmness and soil moisture, temperature and texture (Thomas 1984). Inclusion of crop density as a variable in regression models describing yield losses due to weeds in canola may be of critical importance. In related studies, safflower (Carthamus tinctorius L.) yield losses due to green foxtail also were influenced considerably by safflower plant density (Blackshaw 1993c). Designing weed interference studies with both weed and crop density as the major variables would improve the precision of crop yield loss and economic threshold estimates.

Environmental factors can also influence crop/weed interactions, and some attempts have been made to incorporate environmental variables into regression models in an effort to improve precision. The combined effect of precipitation and growing-degree days was an important component of a model developed to predict wheat yield loss due to interference by weed communities dominated by green foxtail (Hume 1989). Similarly, inclusion of early-season temperature and precipitation in a multiple regression equation provided a better description of the relationship between wheat yield loss and green foxtail density than including only green foxtail density (Peterson and Nalewaja 1992). Inclusion of environmental variables may be important with species such as green foxtail that have the $C_{4}$ pathway of photosynthesis. How- ever, difficulty in accurately predicting climatic conditions at the time a decision on spraying is about to be made may preclude the usefulness of such models. The development of standard protocols across locations and years, through greater coordination among weed ecologists engaged in weed interference research, may be an effective way of enhancing the relevance and precision of weed/crop interference models (Lotz et al. 1996).

\section{Single vs. multiple species thresholds}

Most weed interference experiments have tended to investigate the effects of a single species on crop yield (Table 1). In some cases, this approach can be justified by the fact that relatively expensive herbicides have been developed and marketed to specifically control strong competitors such as wild oats, quackgrass and Canada thistle, which are often dominant species on western Canadian farms. Some multiple species yield loss models have been developed (Coble 1985; Spitters 1983; Wilson 1986). Parameter estimates for most of these models are based on single-species weed interference experiments. Coble (1985) assumes that the interference effects of all weed species are additive at low densities $1<50$ plants $\mathrm{m}^{-2}$ ). At higher densities, competitive indices calculated from linear regression analysis were used to fit the ronlinear model shown in Eq. [2]. This approach forms the basis of a microcomputer decision system (HERB) developed to determine the economics of weed control in soybean [Glycine max (L.) Merrill] (Wilkerson et al. 1991). In Germany, weeds were simply classified into groups of similar perceived competitiveness (e.g., monocotyledons and dicotyledons) and were assigned competitive indices on that basis (Gerowitt and Heitefuss 1990).

Summing weed competitive indices has been criticised on the basis that the combined competitive effects of weeds are rarely additive (at least at high densities) due to weed/weed competition (Alex 1970; Hume 1989). Cousens (1992) suggested that considerably more work is required on modelling the impact of multiple weed species on crop yield to 
accurately predict crop yield losses due to weeds in the field. While this may be true, there have been few suggestions as to how experiments should be designed to accomplish this. The complexities involved in designing such experiments may be difficult to overcome. In a study conducted in western Canada, a linear multiple regression model was developed to predict wheat yield losses due to a natural multi-species weed community dominated by green foxtail (Hume 1989). While this approach has merit in that it overcomes the problem associated with additive competitive effects, the resources required to model the effects of every possible weed community on crop yield may preclude its implementation.

If multi-species weed threshold models are to be used as aids in the decisionmaking process, the general approaches of Coble (1985) and Gerowitt and Heitefuss (1990) may have to be accepted along with a realm of inaccuracy in the predictions due to weed/weed intraspecific competition. Swinton et al. (1994) modified Eq. [2] to predict interference by multiple weed species. The model implies that, as the combined density of all weed species increases, crop yield declines at a diminishing rate. The approach may offer a more biologically reasonable alternative to that of Coble (1985).

\section{Realistic sampling methodology}

One of the major constraints to the practical utilization of weed economic thresholds at the farm level is a dearth of realistic, practical methodology for accurately sampling weed infestations over large areas. Gerowitt and Heitefuss (1990) suggested that less than $1 \mathrm{~h}$ is necessary to assess the weed infestation of a 3-5 ha field with 20-30 random quadrats. Suggested sampling methodology for the computer program HERB was one sample unit in each 0.4 ha with a minimum of 10 samples in a field (Wilkerson et al. 1991). In western Canada, sampling methodology for weed surveys recommended that the field be sampled in a $\mathrm{W}$ pattern, with at least 20 samples per 32ha field (Thomas 1985). Most of the suggested sampling procedures appear to have been conceived arbitrarily. One of the few studies to determine sampling efficiency objectively was conducted in the United Kingdom (Marshall 1988). He concluded that precise estimates of grass weed density could be achieved only at a high sampling intensity of at least 18 locations per hectare. This is not very encouraging since it implies that sampling could be so time consuming that it may be impractical at the farm level. The relevance of this to Canadian farms is difficult to determine at present, since a similar study has not been conducted in Canada.

Most yield loss models have been based on relatively uniform distributions of weeds in carefully managed experimental plots. Monitoring of weed populations and calculation of economic thresholds can be confounded and hindered by the fact that weeds in a field rarely are distributed randomly but tend to be patchy or clumped (Wiles et al. 1993). This clustering of weed populations has been well described by a negative binomial distribution (Marshall 1988). Crop yield loss estimates based on random and negative binomial weed distributions were compared in studies conducted in the United Kingdom (Brain and Cousens 1990; Thornton et al. 1990). The authors concluded that under farm conditions, crop yield loss estimates will be overestimated by models that assume a random weed distribution. The soybean decision model (HERB) was modified recently to incorporate uncertainty due to weed patchiness (Wiles et al. 1993). This resulted in improved decision making in most but not all cases.

There is obviously a need for increased research effort to determine appropriate and realistic weed monitoring procedures for Canadian crop production systems if weed economic thresholds are to have a practical application. This need could be addressed at least in part by attempting to validate current yield loss models in a manner similar to that of Hamman (1979); such work should take precedence over further weed-density-related interference research. There is also a need to determine the importance of weed aggregation in terms of the reliability of weed interference models presently available. Brain and Cousens (1990) suggested that aggregation may be more important at high than at low (close to threshold) weed densities. 


\section{The implications of seed rain}

The single-season weed economic threshold concept has been criticized on the premise that long-term implications of weed seed production can be of considerable importance, but are rarely considered. For this reason, the use of singleseason thresholds for barnyardgrass [Echinochloa crus-galli (L.) Beauv.] management in sugarbeets (Beta vulgaris L.) (Norris 1992b) and for velvetleaf (AbutiIon theophrasti Medic.) management in corn (Zea mays L.) (Sattin et al. 1992) has been described as an unsound management practice. Long-term (10-15 yr) weed management simulation models have been developed for slender foxtail (Alopecurus myosuroides Huds.) (Doyle et al. 1986) and wild oats (Cousens et al. 1986) in winter wheat, and for velvetleaf and common sunflower (Helianthus annuus L.) in soybean (Bauer and Mortensen 1992). The models accounted for seed production by uncontrolled weeds, thus estimating weed thresholds that optimize returns over a number of years. Such thresholds are referred to as economic optimum thresholds (Cousens et al. 1985), to differentiate them from single-season thresholds which are concerned only with financial returns in a single growing season. In winter wheat, the ratio of the economic optimum threshold to the single season threshold was 1:4 (Cousens et al. 1985).

In Canada, few interference studies have addressed the long-term implications of seed production or rhizome or root regeneration (in the case of perennials) by uncontrolled weeds. In a 3-yr study, jimsonweed (Datura stramonium L.) seed production did not decline significantly until populations were well below the threshold densities determined for soybean yields and was influenced by crop planting date and row spacing (Weaver 1986). Weed and crop density (Blackshaw 1993c; O'Donovan 1994b), relative times of emergence of the weed and crop (Blackshaw 1993b; O'Donovan 1992, 1994a), crop rotation (O'Donovan 1988) and fertilizer placement (Yochim et al. 1994) can also influence weed seed and seedling population dynamics. Future weed interference studies should address long-term weed population dy- namics as influenced by these factors. Such information would indicate the cropping systems, agronomic practices and crop/weed complexes most favourable (and unfavourable) to the practical application of the weed economic threshold concept. The development of this information may be crucial to the acceptance and implementation of single-season and economic optimum weed thresholds in Canada. Perceived long-term problems associated with seed production by uncontrolled weeds have been a major constraint to the implementation of weed thresholds and the broader concept of integrated weed management. Rhizome or root regeneration by uncontrolled perennial weeds may also have serious long-term implications. For example, roots of uncontrolled Canada thistle plants can expand at the rate of $1 \mathrm{~cm} \mathrm{~d}^{-1}$ and reach a depth of $1.8 \mathrm{~m}$ in $2 \mathrm{yr}$ (Nadeau and Vanden Born 1989).

\section{BEYOND THE THRESHOLD CONCEPT}

The results of weed interference studies designed to investigate the various factors that influence crop/weed interactions and weed economic thresholds have provided valuable lessons in integrated weed management that go beyond the threshold concept. Planting high quality seed of competitive crops in appropriate rotations and manipulating factors such as crop seeding rate (Blackshaw 1993c; O'Donovan 1994b; O'Donovan et al. 1988, 1989), row spacing (Kirkland 1993), and fertility placement (Yochim et al. 1994) can reduce the impact of weeds on crop yield and reduce the amount of weed seed entering the soil. Adopting agronomic practices that ensure early emergence of the crop relative to the weed can also provide an advantage to the crop (Blackshaw 1993a; O'Donovan 1992; O'Donovan et al. 1985). Seeding crops relatively shallowly as soon as possible after a tillage operation (or pre-seeding herbicide application in a zero tillage system) will likely result in the crop emerging ahead of the weeds with minimal impact in terms of crop yield loss and weed seed production. 
Kirkland (1993) suggested that growers can manage weeds adequately in spring barley without the use of chemicals by varying crop seeding rate and row spacing to favour the crop. In most situations, however, it is more likely that integrating these factors with rational herbicide use would be a more effective long-term strategy. For example, a combination of zero tillage, banded nitrogen, and herbicide application, reduced green foxtail populations to background levels in $4 \mathrm{yr}$ of continuous barley (Yochim et al. 1994). Further studies are necessary to determine if this strategy is effective with other weeds. A combination of relatively high crop densities, narrow row spacing, shallow seeding, and banded nitrogen may provide a highly effective long-term weed management strategy when integrated with limited herbicide use.

Future weed ecology studies in Canada should emphasize the effects of the crop on the weed (Blackshaw 1993c; Kirkland 1993; Légère and Deschênes 1989; Malik et al. 1993; O'Donovan 1994b) rather than the weed on the crop. This would enhance and broaden the relevance of the results in terms of the overall concept of integrated weed management.

\section{DISCUSSION}

A major problem with acceptance of the threshold concept and the broader concept of integrated weed management is that excessive emphasis has been placed on risk associated with not controlling weeds with herbicides. Thus, precision in terms of assessing crop yield losses in a single growing season and, more importantly, the long-term impact of seed rain (Norris 1992a) are considered of paramount importance. In view of the complexity of crop/weed interactions, achieving this precision with the goal of eliminating all risk may indeed be a pipe dream. Thresholds, and the bioeconomic models and decision support systems associated with them, should be considered more as aids in taking some of the subjectivity out of the decision-making process. There is certainly some risk associated with not spraying, especially in the case of prolific seed producers such as barnyardgrass (Norris 1992b) and velvetleaf (Sattin et al. 1992). However, there may even be more risk associated with prophylactic spraying in terms of lost revenue, damage to the environment and possible development of resistant weed populations.

Many of the fears associated with the use of single-season thresholds, in terms of losing revenue within a growing season, are probably unfounded. There is compelling evidence (both direct and indirect) that crop yield loss and economic threshold models tend to overestimate the need for herbicide use. In weed interference experiments (from which the models were developed), crops and weeds usually were seeded to emerge close to the same time. This does not always occur in farmers' fields. Strongly competitive crops such as wheat and barley, the main field crops grown in western Canada, tend to establish faster than most weeds, including wild oats (Cousens et al. 1991; Pavlychenko and Harrington 1934). Where these crops emerged ahead of green foxtail and pale smartweed (Polygonum lapathifolium L.), crop yield loss and weed biomass production were minimal (O'Donovan 1994a).

Most yield loss models also assume that weed populations are distributed in a uniform fashion in fields, whereas in reality weed distribution is usually patchy. Models based on uniform weed distribution will overestimate crop losses due to weeds where distribution is patchy (Brain and Cousens 1990; Thornton et al. 1990). In Germany, the use of fixed thresholds resulted in a large number of wrong decisions for weed populations above the threshold, with only a few below the threshold (Gerowitt and Heitefuss 1990). In western Canada, a regression model developed to estimate wheat yield losses based on density and relative time of emergence of wild oats (O'Donovan et al. 1985) overestimated the effects of wild oats on wheat and barley yield in farmers' fields (M. Goodwin, personal communication). The possibility of farmers or other decision makers erring on the side of underestimating the need for herbicide application through the implementation of single-season weed economic threshold models appears to be slight. Prophylactic herbicide application 
is far more likely to result in a large number of wrong decisions.

Cousens (1987) suggested that, in terms of herbicide use in the United Kingdom, farmers would not use extreme prophylaxis. This is not true in western Canada. On many farms in Alberta, virtual continuous use (in some cases more than $20 \mathrm{yr}$ ) of the preemergence herbicide triallate [S-(2,3,3-trichloro-2-propenyl) bis(1methylethyl)carbamothioate], selected for wild oats that are highly resistant to the product (O'Donovan et al. 1994a). Interviews with some of these farmers (O'Donovan, unpublished data) suggested that the wild oats infestations after many years of triallate use were as bad or worse than those present when the herbicide was first used. Similarly, multiple-year herbicide applications resulted in wild oats (Heap et al. 1993) and green foxtail (Morrison et al. 1989) resistance to various herbicide groups in Manitoba. It is highly unlikely that the farmers involved monitored their fields prior to herbicide application. It is also unlikely that weed populations exceeded the economic threshold each year. Observations by the author, and those of M. Goodwin (personal communication), suggest that many western Canadian farmers apply herbicides for wild oats control at infestations below 1 plant $\mathrm{m}^{-2}$. Yet it is evident from Figures 1 and 2 that even at relatively high crop prices and expected crop yields, wild oats thresholds were at least 9 plants $\mathrm{m}^{-2}$ for barley, and 3 plants $\mathrm{m}^{-2}$ for wheat and canola. For reasons discussed earlier, these thresholds probably were underestimated. Thus, there appears to be considerable scope for reducing herbicide use through implementation of the threshold concept, at least for wild oats.

In Canada, at present, there is little or no evidence that farmers objectively assess the need for herbicide use in terms of counting or otherwise assessing weed populations prior to spraying. A major reason for this may be a reluctance to allow weeds to produce seed in their fields, and a reluctance on the part of extension personnel to advise them to do so. The concept of "zero threshold" suggested by Norris (1985) reinforces this perspective. It is often forgotten that a wealth of herbicide technology is available to control heavy populations of most weed species. The potential loss of this herbicide technology through the development of herbicide resistance may pose a far greater threat to crop production in Canada than perceived problems associated with increases in future weed populations. If herbicide resistance and other negative aspects of prophylactic herbicide use are to be avoided, the threshold concept and associated rational approaches to herbicide use must be taken a lot more seriously in Canada than they are at present.

The practical application of the weed threshold concept would be facilitated greatly by the development of user-friendly computerized decision support systems adapted for specific cropping systems in Canada. A computer program designed to estimate the profitability of controlling different densities of early and late emerging wild oats in cereals (M. Goodwin, unpublished data) is the only such system currently available to western Canadian producers.

\section{ACKNOWLEDGMENTS}

I am grateful to Mark Goodwin, former weed specialist with the Manitoba Department of Agriculture, for his valuable comments and suggestions, and to Drs. Phil Lee and Gordon Thomas, and several anonymous reviewers for their critical evaluations of the manuscript.

\section{REFERENCES}

Alex, J.F. 1970. Competition of Saponaria vaccaria and Sinapis arvensis in winter wheat. Can. J. Plant Sci. $50:$ 379-388.

Bauer, T.A., and D.A. Mortensen. 1992. A comparison of economic and economic optimum thresholds for two annual weeds in soybeans. Weed Technol. $6: 228-235$.

Bitterlich, G., and M.H. Upadhyaya. 1990. Lamb's-quarters interference with clirect seeded broccoli. Can. J. Plant Sci. 70 : 1215-1221.

Blackshaw, R.E. 1991. Hairy nightshade (Solanum sarrachoides) interference in dry beans (Phaseolus vulgaris). Proc. $44^{\text {th }}$ Meeting West. Soc. Weed Sci. 44 : 19-21. 
Blackshaw, R.E. 1993a. Downy brome (Bromus tectorum) density and relative time of emergence affects interference in winter wheat (Triticum aestivum). Weed Sci. 41 : 551-556.

Blackshaw, R.E. 1993b. Downy brome (Bromus tectorum) interference in winter rye (Secale cereale). Weed Sci. $41:$ 557-562.

Blackshaw, R.E. 1993c. Safflower (Carthamus tinctorius) density and row spacing effects on competition with green foxtail ( $\mathrm{Se}$ taria viridis). Weed Sci. $41:$ 403-408.

Blackshaw, R.E., E.H. Stobbe, and A.R.W. Sturko. 1981. Effect of seeding dates and densities of green foxtail (Setaria viridis) on the growth and productivity of spring wheat (Triticum aestivum). Weed Sci. 29 : 212-217.

Blackshaw, R.E., G.W. Anderson, and J. Dekker. 1987. Interference of Sinapis arvensis L. and Chenopodium album L. in spring rapeseed (Brassica napus L.). Weed Res. $27: 207-213$.

Brain, P., and R. Cousens. 1990. The effect of weed distribution on predictions of yield loss. J. Appl. Ecol. 27 : 735-742.

Carlson, H.L., and J.E. Hill. 1985. Wild oat (Avena fatua) competition in spring wheat. Weed Sci. 33 : 176-181

Coble, H.D. $1985 . \quad$ Multi-species number thresholds for soybeans. Proc. Weed Sci. Soc. Am. 25 : 59 (Abstract).

Cousens, R. 1985. A simple model relating yield loss to weed density. Ann. Appl. Biol. 107 : 239-252.

Cousens, R. 1987. Theory and reality of weed control thresholds. Plant Prot. Quart. 2: 13-20.

Cousens, R.D. 1992. Weed competition and interference in cropping systems. Pages 113-117 in : J.H. Combellack, K.J. Levick, J. Parsons, and R.G. Richardson (eds.), Proc. $1^{\text {st }}$ Int. Weed Control Congress, Melbourne, Australia; Weed Sci. Soc. of Victoria, vol. 1

Cousens, R., B.J. Wilson, and G.W. Cussans. 1985. To spray or not to spray : the theory behind the practice. Proc. Br. Crop Prot. Conf. Weeds, vol. 3, p. 671-678.

Cousens, R., C.J. Doyle, B.J. Wilson, and G.W. Cussans. 1986. Modelling the economics of controlling Avena fatua in winter wheat. Pestic. Sci. $17:$ 1-12.

Cousens, R., P. Brain, J.T. O'Donovan, and P.A. O'Sullivan. 1987. The use of biologically realistic equations to describe the effects of weed density and relative time of emergence on crop yield. Weed Sci. 35 : 720-725.

Cousens, R.D., S.E. Weaver, T.D. Martin, A.M. Blair, and J. Wilson. 1991. Dynamics of competition between wild oats (Avena fatua L.) and winter cereals. Weed Res. $31: 203-210$.

De St. Remy, E.A., J.T. O'Donovan, A.K.W. Tong, P.A. O'Sullivan, M.P. Sharma, and D.A. Dew. 1985. Influence of Tartary buckwheat (Fagopyrum tataricum) density on yield loss of barley (Hordeum vulgare) and wheat (Triticum aestivum). Weed Sci. 33 : 521-523.

Dew, D.A. 1972. An index of competition for estimating crop loss due to weeds. Can. J. Plant Sci. 52 : 921-927.

Dew, D.A., and C.H. Keys. 1976. An index of competition for estimating loss of rape due to wild oats. Can. J. Plant Sci. $56: 1005-$ 1006.

Douglas, D.W., A.G. Thomas, D.P. Peschken, G.G. Bowes, and D.A. Derksen. 1991. Effects of summer and winter scentless chamomile (Matricaria perforata Mérat) interference on spring wheat yield. Can. J. Plant Sci. $71: 841-850$.

Douglas, D.W., A.G. Thomas, D.P. Peschken, G.G. Bowes, and D.A. Derksen. 1992. Scentless chamomile (Matricaria perforata Mérat) interference in winter wheat. Can. J. Plant Sci. 72 : 1383-1387.

Doyle, C.J., R. Cousens, and S.R. Moss. 1986. A model of the economics of controlling Alopecurus myosuroides Huds. in winter wheat. Crop Prot. 5 : 143-150.

Evans, R.M., D.C. Thill, L. Tapia, B. Shafii, and J.M. Lish. 1991. Wild oats (Avena fatua) and spring barley (Hordeum vulgare) density affect spring barley grain yield. Weed Technol. 5 : 33-39.

Friesen, L., I.N. Morrison, G. Marshall, and W. Rother. 1990. Effects of volunteer wheat and barley on the growth and yield of flax. Can. J. Plant Sci. 70 : 1115-1122.

Friesen, L.F., K.P. Nickel, and I.N. Morrison. 1992. Round-leaved mallow (Malva pusilla) growth and interference in spring wheat (Triticum aestivum) and flax (Linum usitatissimum). Weed Sci. $40:$ 448-454.

Gerowitt, B., and R. Heitefuss. 1990. Weed economic thresholds in cereals in the Federal Republic of Germany. Crop Prot. 9 : 323-331. 
Hamman, W.M. 1979. Field confirmation of an index for predicting yield losses of wheat and barley due to wild oat competition. Can. J. Plant Sci. 59 : 243-244.

Heap, I.M., B.G. Murray, H.A. Loeppky, and I.N. Morrison. 1993. Resistance to aryloxyphenoxypropionate and cyclohexanedione herbicides in wild oat (Avena fatua). Weed Sci. 41 : 232-238.

Hume, L. 1985. Crop losses in wheat (Triticum aestivum) as determined using weeded and nonweeded quadrats. Weed Sci. 33 : 734-740.

Hume, L. 1989. Yield losses in wheat due to communities dominated by green foxtail [Setaria viridis (L.) Beauv.] : A multi-species approach. Can. J. Plant Sci. 69 : 521529.

Jolliffe, P.A., A.N. Minijas, and V.C. Runeckles. 1984. A reinterpretation of yield relationships in replacement series experiments. J. Appl. Ecol. 21 : 227-243.

Kirkland, K.J. 1993. Weed management in spring barley (Hordeum vulgare) in the absence of herbicides. J. Sust. Agric. 3 : 95-104.

Kirkland, K.J., and J.H. Hunter. 1991. Competitiveness of Canada prairie spring wheats with wild oat (Avena fatua L.) Can. J. Plant Sci. 71: 1089-1092.

Kropff, M.J., and C.J.T. Spitters. 1991. A simple model of crop loss by weed competition from early observations on relative leaf area of weeds. Weed Res. 31: 97105.

Légère, A., and J.M. Deschênes. 1989. Effects of time of emergence, population density and interspecific competition on hempnettle (Galeopsis tetrahit) seed production. Can. J. Plant Sci. 69 : 185-194.

Légère, A., and J.M. Deschênes. 1991. Yield responses of oats and alfalfa to common hemp-nettle (Galeopsis tetrahit) interference. Can. J. Plant Sci. 71: 141-147.

Lotz, L.A.P., S. Christensen, D. Cloutier, C. Fernandez Quintanilla, A. Légère, C. Lemieux, P.J.W. Lutman, A. Pardo Iglesias, J. Salonen, M. Sattin, L. Stigliani, and F. Tei. 1996. Prediction of the competitive effects of weeds on crop yields based on the relative leaf area of weeds. Weed Res. $36: 93-101$

Malik, V.S., C.J. Swanson, and T.E. Michaels. 1993. Interaction of white bean (Phaseolus vulgaris L.) cultivars, row spacing and seeding density with annual weeds. Weed Sci. $41:$ 62-68.
Marra, M.C., and G.A. Carlson. 1983. An economic threshold model for weeds in soybeans. Weed Sci. 31 : 604-609.

Marshall, E.J.P. 1988. Field estimates of grass weed populations in arable land. Weed Res. 28 : 191-198.

Marshall, G., I.N. Morrison, L. Friesen, and W. Rother. 1989. Effects of volunteer wheat and barley on the growth and yield of rapeseed. Can. J. Plant Sci. 69 : 445-453.

McLennan, B.R., R. Ashford, and M.D. Devine. 1991. Cirsium arvense (L.) Scop. competition with winter wheat (Triticum aestivum L.). Weed Res. 31: 409-415.

Morin, C., D. Blanc, and H. Darmency. 1993. Limits of a simple model to predict yield losses in maize. Weed Res. 33 : 261-268.

Morrison, I.N., B.G. Todd, and K.M. Nawolsky. 1989. Confirmation of trifluralin resistant green foxtail (Setaria viridis) in Manitoba. Weed Technol. 3 : 544-551.

Moyer, J.R., and G.B. Schaalje. 1993. Quackgrass (Elytrigia repens) interference and control in seed alfalfa (Medicago sativa). Weed Technol. 7 : 58-64.

Moyer, J.R., G.B. Schaalje, and P. Bergen. 1991. Alfalfa (Medicago sativa) seed yield loss due to Canada thistle (Cirsium arvense). Weed Technol. 5 : 723-728.

Nadeau, L.B., and W.H. Vanden Born. 1989. The root system of Canada thistle. Can. J. Plant Sci. 69 : 1199-1206.

Norris, R.F. 1985. Weed populations dynamics and the concept of zero thresholds. Proc. Weed Sci. Soc. Am. $25: 58$ (Abstract).

Norris, R.F. 1992a. Have ecological and biological studies improved weed control strategies? Pages 7-28 in : J.H. Combellack, K.J. Levick, J. Parsons, and R.G. Richardson (eds.), Proc. $1^{\text {st }}$ Int. Weed Control Congress, Melbourne, Australia; Weed Sci. Soc. of Victoria, vol. 1.

Norris, R.F. 1992b. Case history for weed competition/population ecology: Barnyardgrass (Echinochloa crus-galli) in sugarbeets (Beta vulgaris). Weed Technol. 6: 220227.

O'Donovan, J.T. 1988. Wild oat (Avenál fatua) infestations and economic returns as influenced by frequency of control. Weed Technol. 2 : 495-498.

O'Donovan, J.T. 1991. Quackgrass (Elytrigia repens) interference in canola (Brassica campestris). Weed Sci. 39 : 397-401. 
O'Donovan, J.T. 1992. Seed yields of canola and volunteer barley as influenced by their relative times of emergence. Can. J. Plant Sci. 72 : 263-267.

O'Donovan, J.T. 1994a. Green foxtail (Setaria viridis) and pale smartweed (Polygonum lapathifolium) interference in field crops. Weed Technol. $8: 311-316$.

O'Donovan, J.T. 1994b. Canola (Brassica rapa) plant density influences Tartary buckwheat (Fagopyrum tataricum) interference, biomass and seed yield. Weed Sci. 42 : 385-389.

O'Donovan, J.T., E.A. De St. Remy, P.A. O'Sullivan, and D.A. Dew. 1985. Influence of the relative time of emergence of wild oat (Avena fatua) on yield loss of barley (Hordeum vulgare) and wheat (Triticum aestivum). Weed Sci. 33 : 498-503.

O'Donovan, J.T., A.K. Sharma, K.J. Kirkland, and E.A. De St. Remy. 1987. The effect of volunteer barley on the yield and profitability of rapeseed in western Canada. Proc. Br. Crop Prot. Conf. - Weeds 3 : 10351041.

O’Donovan, J.T., A.K. Sharma, K.J. Kirkland, and E.A. De St. Remy. 1988. Volunteer barley (Hordeum vulgare) interference in canola (Brassica campestris and B. napus). Weed Sci. 36 : 734-739.

O'Donovan, J.T., K.J. Kirkland, and A.K. Sharma. 1989. Canola yield and profitability as influenced by volunteer wheat infestations. Can. J. Plant Sci. 69 : 1235-1244.

O’Donovan, J.T., M.P. Sharma, K.N. Harker, D. Maurice, M.N. Baig, and R.E. Blackshaw. 1994a. Wild oat (Avena fatua) populations resistant to triallate are also resistant to difenzoquat. Weed Sci. 42: 195-199.

O’Donovan, J.T., G.M. Jeffers, D. Maurice, and M.P. Sharma. 1994b. Investigation of a chlorsulfuron resistant chickweed (Ste)laria media) population. Can. J. Plant Sci. 74 : 693-697.

O'Sullivan, P.A., V.C. Kossatz, G.M. Weiss, and D.A. Dew. 1982. An approach to estimating yield loss of barley due to Canada thistle. Can. J. Plant Sci. 62 : 725-731.

O'Sullivan, P.A., G.M. Weiss, and V.C. Kossatz. 1985. Indices of competition for estimating rapeseed yield loss due to Canada thistle. Can. J. Plant Sci. 65 : 145149.

Pageau, D., and G.D. Leroux. 1988. Threshold density of quackgrass [Agropyron repens (L.) Beauv.] in alfalfa (Medicago sativa L.). Can. J. Plant Sci. 68: 121-130.
Pavlychenko, T.K., and J.B. Harrington. 1934. Competitive efficiencies of weeds and cereal crops. Can. J. Res. $10: 77-94$.

Peschken, D.P., A.G. Thomas, and R.F. Wise. 1983. Loss in yield of rapeseed (Brassica napus, $B$. campestris) caused by perennial sowthistle (Sonchus arvensis) in Saskatchewan and Manitoba. Weed Sci. 31: 740744.

Peterson, D.E., and J.D. Nalewaja. 1992. Green foxtail (Setaria viridis) competition with wheat (Triticum aestivum). Weed Technol. $6: 291-296$.

Poole, M.L., and G.S. Gill. 1987. The use of weed density-crop yield relationships for predicting yield loss in the field. Proc. Br. Crop Prot. Conf. Weeds 3 : 945-954.

Radford, B.J., B.J. Wilson, O. Cartledge, and F.B. Watkins. 1980. Effect of wheat seeding rate on wild oat competition. Austr. J. Exp. Agric. Anim. Husb. 20 : 77-81.

Rioux, R. 1982. La mesure de l'interférence du chiendent dans l'orge. Can. J. Plant Sci. 62 : 183-188.

Sattin, M., G. Zanin, and A. Bert. 1992. Case history for weed competition/population ecology: Velvetleaf (Abutilon theophrasti) in corn (Zea mays). Weed Technol. 6 : 213219.

Spitters, C.J.T. 1983. An alternative approach to the analysis of mixed cropping systems. 1. Estimation of competition effects. Neth. J. Agric. Sci. $31: 1-11$

Swanton, C.J., and S.F. Weise. 1991. Integrated weed management: the rationale and approach. Weed Technol. 5 : 657-663.

Swinton, S.M., D.D. Buhler, F. Forcella, J.L. Gunsolus, and R.P. King. 1994. Estimation of crop yield loss due to interference by multiple weed species. Weed Sci. 42 : 103109.

Thomas, P. 1984. Canola growers manual. Canola Council of Canada Publ., Winnipeg, Manitoba, Canada, 1424 pp.

Thomas, A.G. 1985. Weed survey system used in Saskatchewan for cereal and oilseed crops. Weed Sci. 33 : 34-43.

Thornton, P.K., R.H. Fawcett, J.B. Dent, and T.J. Perkins. 1990. Spatial weed distribution and economic thresholds for weed control. Crop Prot. 9 : 337-342.

Van Acker, R.C., S.F. Weise, and C.J. Swanton. 1993. Influence of interference from a mixed weed species stand on soybean [Glycine max (L.) Merr.] growth. Can. J. Plant Sci. 73 : 1293-1304. 
Wall, D.A. 1993. Wild mustard (Sinapis arvensis L.) competition in navy beans. Can. J. Plant Sci. 73 : 1309-1313.

Wall, D.A., and G.H. Friesen. 1990. Green foxtail (Setaria viridis) competition in potato (Solanum tuberosum). Weed Sci. 38 : 396-400.

Wall, D.A., and I.N. Morrison. 1990. Competition between Silene vulgaris (Moench) Garcke and alfalfa (Medicago sativa L.). Weed Res. 30 : 145-151.

Wall, D.A., G.H. Friesen, and T.K. Bhati. 1991. Wild mustard interference in traditional and semi-leafless field peas. Can. J. Plant Sci. $71: 473-480$.

Weaver, S.E. 1986. Factors affecting threshold levels and seed production of jimsonweed (Datura stramonium L.) in soybeans (Glycine max (L.) Merr.). Weed Res. 26 : 215-223.

Weaver, S.E. 1991. Size-dependent economic thresholds for three broadleaf weed species in soybeans. Weed Technol. 5 : 674-679.
Weaver, S.E., N. Smits, and C.S. Tan. 1987. Estimating yield losses of tomatoes ( $\mathrm{LyCO}$ persicon esculentum) caused by nightshade (Solanum spp.) interference. Weed Sci. 35 : 163-168.

Wiles, L.J., H.J. Gold, and G.G. Wilkerson. 1993. Modelling the uncertainty of weed density estimates to improve post-emergence herbicide control decisions. Weed Res. 33 : 241-252.

Wilkerson, G.G., S.A. Modena, and H.D. Coble. 1991. HERB : Decision model for postemergence weed control in soybean. Agron. J. $83: 413-417$.

Wilson, B.J. 1986. Yield responses of winter cereals to the control of broad-leaved weeds. Proc. Eur. Weed Res. Soc. Symp., p. 75-82.

Yochim, A.D., J.T. O'Donovan, D.W. McAndrew, and M. Gorda. 1994. Banding nitrogen: an effective management tool for green foxtail in continuous barley. Proc. West. Soc. Weed Sci. $47: 27$ (Abstract). 